\title{
HIGHER EDUCATION AND INCOME DISTRIBUTION IN A LESS DEVELOPED COUNTRY
}

\author{
GARY S. FIELDS ${ }^{1}$ \\ Yale University
}

Three competing hypotheses have been advanced concerning the effect of government education spending and finance on income distribution. One hypothesis is that educational spending leads to income redistribution in favour of the poor. The alternative hypothesis is that educational spending results in an even wider gap between rich and poor. Finally, there is the null hypothesis, which holds that the aggregate distribution of income is determined by many things other than education which, by this hypothesis, has little or no effect. These hypotheses apply to the effects of education spending and finance on the size distribution of income within a generation and to the effects upon movement between (relative) income classes between generations.

The primary purpose of this paper is to empirically test among both the intra- and the inter-generational version of these three hypotheses for higher (i.e. post-secondary) $)^{2}$ levels of education for one less developed country, Kenya. ${ }^{3} \mathrm{~A}$ secondary purpose is to investigate other economic aspects of spending on higher education, most notably the question of horizontal equity in school finance.

Before proceeding, a methodological point is in order. There is no consensus in the public economics literature on what is a suitable criterion for assessing the equitability of a fiscal programme. ${ }^{4}$ At least three criteria may be distinguished (the terminology is my own): (1) The Equal Opportunity Criterion. By this criterion, a fiscal programme is equitable if different groups in the population have access to the programme in proportion to their numbers in the population, irrespective of the costs paid by the different groups in relation to benefits received. (2) The Cost-Benefit Criterion. By this criterion, a fiscal programme is equitable if the costs paid by different groups in the population are proportional to the benefits they each receive, irrespective of access to the programme. (3) The Ability to Pay Criterion. By

\footnotetext{
1 This paper was began when the author was Visiting Research Associate, Institute for Development Studies, University of Nairobi; continued at the Chr. Michelson Institute, Bergen, Norway; and completed at the Economic Growth Center, Yale University. Thanks are extended to the above institutions and to the Rockefeller Foundation, which provided the financial support for the author's stay in Kenya. John Akin, William Neenan, Svein-Erik Rested, and David Stern provided helpful comments during the preparation of this paper. Finally, I wish to thank Julia Collins for her invaluable research assistance. 2 Regrettably, no data exist to permit similar tests for lower levels of education.

3 The Kenya data are particularly rich, especially for a less developed country. None the less, many assumptions and
} approximations have had to be made. The reader should bear the fragmentary nature of the underlying data in mind and interpret what follows with care.

${ }^{4}$ The methodology utilized here is similar in a number of respects (though different in many others) to that used in a study of California's higher education system by Hansen and Weisbrod [4], An illuminating controversy on their work involving, among others, Joseph Pechman [8], has questioned the conceptual framework for evaluating the income distribution effects of a fiscal programme. The present paper borrows from both without taking either side, and in some ways is most similar to the treatment suggested by Robert Hartman [5]. 
this criterion, due to diminishing marginal utility of income, a programme is equitable if the cost-benefit ratio of the programme rises as a function of income. Evidently, when confronted with a given set of facts, these criteria may yield very different qualitative judgements about the equitability of a fiscal programme. ${ }^{5}$ We note that the cost- benefit and the equal opportunity criteria apply horizontally (i.e. between individuals in the same income class) as well as vertically (i.e. for comparisons across income classes). Note also that the equal opportunity criterion refers primarily to infer-generational distributional effects, whereas the other two are primarily intra-generational.

\section{Students' socio-economic background}

Kenya's educational system consists of seven primary grades (called standards), four years of secondary and two years of higher secondary schooling (called forms), and a post-secondary system comprised of teacher training colleges and a university. ${ }^{6}$ The Kenya government has expressed a strong commitment to equalizing the distribution of income [12, pp. 2-3] and open recruitment to the educational system is seen as one of the main means of bringing this about. However, like many other less developed countries, Kenya has a very steep 'educational pyramid'. The reason this is important is that one cannot simply decide to continue his education and do so. Rather, school admissions are highly competitive, the main criterion being performance on written examinations at the end of a course of study. ${ }^{7}$ There is a great demand for education at all levels relative to the supply. This is because the educational system is almost entirely subsidized find the private benefits of education are very large. For instance, university education is free (except to non-citizens) and the starting salary of a university graduate in the civil service is four times that of a secondary graduate. Consequently, the private rates of return to investment in higher levels of education in Kenya are very high-of the order of 30 percent per year (see Table II below).

These facts-a steep educational pyramid, express public policy in favour of greater income equality, and large private benefits to those few who receive higher education-raise the question of the socio-economic background of the children who receive the rewards. To answer this question, I was able to make use of unpublished data on the characteristics of the parents of university students

1 Consider the following hypothetical example.

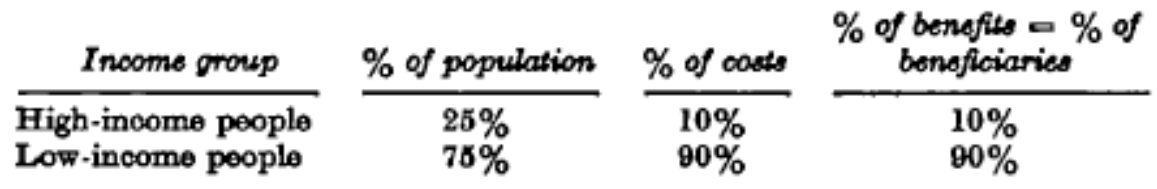

By the cost-benefit criterion, the programme is equitable, because the percentage of costs equals the percentage of benefits for both high and low income people. By the equal opportunity criterion, the programme is inequitable and favours low-income people, who are 75 percent of the population, yet 100 percent of the beneficiaries. By the ability-to-pay criterion, the programme is inequitable and favours high-income people, who despite their higher incomes have the «nun cost-benefit ratio as low-income people. Although this lack of a single equity criterion does not affect the method of analysis, the choice of criterion does affect the interpretation of the results.

6 Out of a total population of 10 million, in 1070 there were 1,300,000 children in primary school, 125,000 in secondary, and 10,000 in postsecondary, of whom 7,000 were in teacher training colleges and the remainder at the University of Nairobi. All these pupils, except for 50,000 secondary students, attended government-operated schools.

${ }^{7}$ Both the examinations and the curriculum reflect the legacy of colonialism and are not very different from the British educational system of today. 
which were already available, ${ }^{8}$ and I supplemented these by personally gathering data from the teacher training colleges. ${ }^{9}$ The basic findings are reported in Table I.

\author{
TABLE I \\ Occupational distribution, educational attainment, and land \\ ownership of fathers of higher education students
}

\begin{tabular}{|c|c|c|c|c|}
\hline & \multicolumn{4}{|c|}{ Educotional attainmens } \\
\hline & $\begin{array}{c}\text { Primary } \\
T T C_{s}\end{array}$ & $\begin{array}{c}\text { Secondary } \\
\text { TTC: }\end{array}$ & $\begin{array}{l}\text { Univerrify } \\
\text { of Nairobi }\end{array}$ & $\begin{array}{c}\text { Reference } \\
\text { group }\end{array}$ \\
\hline \multicolumn{5}{|l|}{ Occupationsl catogory } \\
\hline High and middle level manpowers & $23 \%$ & $19 \%$ & $35 \%$ & $3 \%{ }^{d}$ \\
\hline $\begin{array}{l}\text { Entrepreneurs, traders, and } \\
\text { businessmen }\end{array}$ & $9 \%$ & $8 \%$ & $20 \%$ & \\
\hline Bmall-Bcale farmers & $54 \%$ & $60 \%$ & $44 \%$ & $66 \%$ \\
\hline Unskilled and traditionsl & $14 \%$ & $12 \%$ & $1 \%$ & $31 \%^{\mathrm{d}}$ \\
\hline \multicolumn{5}{|l|}{ Eduastional attainment } \\
\hline None & $49 \%$ & $48 \%$ & $21 \%$ & $80 \%^{\circ}$ \\
\hline At least some primary & $44 \%$ & $48 \%$ & $56 \%$ & $18 \%^{\circ}$ \\
\hline Secondary or beyond & $7 \%$ & $5 \%$ & $22 \%$ & $2 \%^{\circ}$ \\
\hline \multicolumn{5}{|l|}{$\begin{array}{l}\text { \% Landowners } \\
\text { Acreage if landowner }\end{array}$} \\
\hline $0 \cdot 1-4 \cdot 9$ & $34 \%$ & $32 \%$ & $15 \%$ & $52 \% 8$ \\
\hline $6 \cdot 0-24 \cdot 8$ & $56 \%$ & $56 \%$ & $50 \%$ & $41 \%$ \\
\hline 25.0 and over & $10 \%$ & $12 \%$ & $38 \%^{\circ}$ & $7 \%$ \\
\hline
\end{tabular}

ancludes professional, administrative, and managerial, teachers, armed forces and polioe, clerical, ekilled and semi-skilled artisans, and lange-ecale farmers. As defined by the 1967 Manpower Survey, a large-ecale farmer is one who employs fourteen or more lebourers.

b This comprises a mixed group, ranging from high-lovel modern sector to low-level traditional seotor and cannot be allocsted to either catogory.

- Approximate.

a Refarence group is ell adult meles in Kenye. Figures are caloulatod from data in [3] and $[14$, p. 176].

- Reference group is all Afrioan males in Kenye aged 40 and over. Data are taken from [14, pp. 16-17].

T These figures were obtained in the following manner. According to the 1969 Population Census, there ware 2,172,000 Afrioan males aged 20 and over out of a total African population of $10,733,200$. Thus, the proportion of potential landownars to the total population is just over 20 per cont. The fftean distriots for which size distribution of farms wes available from the 1869 emall farms census bad a population in 1969 of 6,827,000. Applying the 20 per cent proportion, there would thus be $1,085,400$ potential landholders. There were 777,000 landholdings in these distriots, or 72 per cent of adult males.

- Refarence group is peroentage of landholdings. Date aro takon from [14, p. 81].

In general, as compared with all adult males in Kenya, the students' parents are more likely to be in a high-level occupation, to

8I wish to thank 8. E. Rastad for making the University data available to me. These data were compiled from personal interviews with 188 students (out of a total graduating class of 220) at the University of Nairobi in 1970. Some of Rastad's results are reported in [9].

${ }^{9}$ During May and June of 19711 visited six of the twenty-four primary teacher training colleges (these six were selected to include one school in each of the four major tribal areas plus two smaller but important tribes) and the two secondary teacher training colleges for the purposes of administering a 'Barents' Occupation Questionnaire'. In all, I received 1,732 usable responses from students in primary teacher training colleges and 449 from students in the secondary TTCs. 
be better educated, to own land, and (if landowners) to have larger landholdings. If these are taken as measures of socio-economic status, we thus observe that Kenyan students come from families with higher-than-average socioeconomic status. This is true for each type of higher education. Moreover, the parents of University of Nairobi students come from an even higher socio-economic background than students at the teacher training colleges. Thus, we find that the children of the relatively well-to-do tend to benefit more from Kenya's higher education system than the children of poorer families and that this tendency is most pronounced at the university level.

If all families contributed equally to the financing of the school system, these findings would in and of themselves indicate that the educational system is financed inequitably by all of the criteria discussed above. However, one's taxes rise with one's income so it is not clear which income groups gain and which lose from educational spending. Our task in the remaining sections is to find out.

2. Magnitude of the costs and benefits

The magnitudes of the costs and benefits of different types of higher education and private rates of return to investment in each type tire shown in Table II.

\section{TABLE II}

Costs, benefits, and private returns to different types of educational investment in Kenya, 1971

(1 Kenya shilling $=U . S$. $\$ 0.14$ in 1971)

\begin{tabular}{|c|c|c|c|c|}
\hline & & \multicolumn{3}{|c|}{ Educational attainmens } \\
\hline & & $\begin{array}{l}\text { Primary } \\
\text { TTOs }\end{array}$ & $\begin{array}{l}\text { Secondary } \\
\text { TTOs }\end{array}$ & $\begin{array}{l}\text { Univervity } \\
\text { of Nairobi }\end{array}$ \\
\hline $\begin{array}{l}\text { (1) } \\
\text { (2) } \\
\text { (8) }\end{array}$ & $\begin{array}{l}\text { Average annual cost } \\
\text { Booial } \\
\text { Diroct private } \\
\text { Forgone esurnings (undiscounted) }\end{array}$ & $\begin{array}{r}\text { Bhs. } 8,140 \\
0 \\
18,160\end{array}$ & $\begin{array}{r}\text { Shs. } 5,600 \\
0 \\
27,600\end{array}$ & $\begin{array}{r}\text { Shs. } 17,740 \\
0 \\
47,100\end{array}$ \\
\hline (4) & $\begin{array}{l}\text { Total direct subsidy after Form } 4^{\circ} \\
\text { Starting publio service salary (annual })^{d}\end{array}$ & $\begin{array}{l}6,280 \\
8,940\end{array}$ & $\begin{array}{l}16,800 \\
14,040\end{array}$ & $\begin{array}{l}55,600 \\
24,240\end{array}$ \\
\hline $\begin{array}{l}\text { (6) } \\
\text { (7) } \\
\text { (8) } \\
\text { (9) }\end{array}$ & $\begin{array}{l}\text { Privats benefits compared with Form } \mathbf{x}^{\circ} \\
\quad r=0 \% \\
r=5 \% \\
r=10 \% \\
\text { Private internal rate of return over Form } 4^{1}\end{array}$ & $\begin{array}{c}302,820 \\
99,862 \\
37,626 \\
28 \%\end{array}$ & $\begin{array}{c}549,660 \\
192,184 \\
82,882 \\
33 \%\end{array}$ & $\begin{array}{l}771,880 \\
277,182 \\
120,818 \\
31 \%\end{array}$ \\
\hline
\end{tabular}

s These eduastionsl attainments have the following meaning. The six years of eecondary sahooling are known as 'forms'. A student who ompletes Form 4 is recognized as hsving finished secondary sohool. The flgures for primary ahool teachers are for the highest grade teacher (P1), one who completes two years of primary tescher training after Form 4. Likewise, the figures for secondary teachers are for the highest grado socondary teacher (81), one who has completed three years of aecondary teacher training after Form 4. The Univer. sity course requires two years of higher acondary education plus three years of university.

6 Avarage ennual social cost o (recurrent expenditures + amortization of ourrent developmont expenditures + depreoistion on existing espital stock) divided by number of pupils. Bouroe of Row (1): [2, Table 3].

- Total direct subsidy after Form 4 on (Average annual social cost less direct private cost) $X$ number of years required to attain that education level.

d Souroo of Row (5): Ndegwa Commission.

- Construoted on tho (unlikely) asenmption that a Form 4 gradusto would be fully employed at the government salary scelo.

Source of Row (9): [2, Table 4]. 
Looking first at the costs, we see that the direct costs of schooling are entirely subsidized. ${ }^{10}$ Students receive tuition, books, room and board, a clothing allowance, and a very small cash living allowance. The government justifies these fee policies on the grounds that these people are the future leaders of the country and no able person should be discouraged on account of inability to meet the fees.

For the benefits of higher education, we take the public service salary schedule as our standard. The benefit streams shown in rows 6-8 are calculated on the assumptions that a person completes Form 4 at age 19 (the actual average completion age) and retires at age 55 (the compulsory civil service retirement age) and his earnings progress within his initial civil service rank but he is not promoted. ${ }^{11,12}$

\section{Incidence of the indirect costs}

As we have seen, Kenya's higher education system is funded almost entirely by the government. Consequently, in order to determine the incidence of school costs, we must examine the sources of the government's revenues. Duties and excises are the main sources of revenue, with income taxes nearly as great. Graduated Personal Tax (GPT) is the only other single item of any substantial magnitude. The specific revenue sources are discussed briefly below.

\section{A. Revenue sources}

Income taxes

Kenya has both a personal and a corporate income tax which combined account for 35 per cent of the government's revenues. The income tax is administered by the East African Community. ${ }^{13}$ The rate structure of the personal income tax is highly progressive, with marginal rates from 12-5 to 77-5 per cent of chargeable income. The personal income tax provides a single allowance of shs. 4,320, married allowance of shs. 9,600, and children's allowance of shs. 2,400 per child up to a maximum of four. ${ }^{14}$ The allowances for a married man with four children Eire almost 20 times the per capita income. Thus, most families pay no income tax. In 1967, the last year for which data were available, fewer than 35,000 individuals (compared with a population of 10 million) were subject to income tax.

\footnotetext{
10 There are two classes of exceptions to this generalization: foreign students at the University of Nairobi who are not subsidized by the Kenyan government (but who are usually fully subsidized by their own governments), and Kenya residents who are not citizens who receive only partial, not total, subsidies.
}

11 Two objections to the use of the civil service salary scales might be voiced. First, the private sector generally pays higher wages than the public sector. And second, since only the best students (as measured by exams) are able to go on to the next level, only a portion of the additional earnings is attributable to the education itself. To the first objection, we note that nearly all Kenyans who have completed higher education are employed by the government, so that the government salary scale is relevant. On the second point, two facts are important: educational attainment determines the job for which an individual is hired, and the salary is a function of the job. These facts mean that the entire civil service salary differential is the private benefit an individual could expect to receive if he is able to continue his education.

12 No allowance is made for wastage (flunking out or dropping out) since both are rare.

13 The East African Community includes the countries of Kenya, Tanzania, and Uganda. Besides administering income tax collections, the Community operates such services as posts and telecommunications, railways and harbours, and power in the three counties. The Community also comprises a duty-free common market.

14 In 1971 one Kenyan shilling equaled \$.14 U.S. 
The marginal company income tax rate is 40 per cent. The system of deductions is less generous than in the U.S. and U.K. and other developing countries. ${ }^{15}$

Graduated Personal Tax (GPT)

The GPT, accounting for 5 per cent of revenue, is a graduated lump sum tax, mildly regressive over low income ranges, mildly progressive over high income ranges, and strongly regressive within an income class. The bulk of the tax is collected from low income people. There are no personal allowances or deductions; gross income is the tax base.

\section{Import duties and excise taxes}

These sources together yield 40 per cent of government revenues. The rate structure of import duties is designed to protect local industries, encourage manufacturing by having low or zero rates on inputs, and place heavy taxes on luxuries. Imports from the other countries of the East African Community are exempted from duty. The most important revenue-producing items are fuels, textiles, transport equipment, and food, drink, and tobacco. The bulk of excise revenues were collected from beer, sugar, and cigarettes.

\section{B. Incidence of personal taxes}

Columns 2-5 of Table III present estimates of the incidence of taxation in Kenya. These data are derived largely from a recent study of Kenya's tax system by Westlake [10] [11], who analysed household budget survey data for 1,146 African ${ }^{16}$ households in Kenya's three main urban areas. The most noteworthy feature of column 2 is the regressivity of indirect taxes over the lower brackets which include the vast percentage of the African population. In column 3, we see the regressivity of the over-all tax incidence in the lower brackets. Column 5 indicates that two-thirds of the personal tax burden falls on persons in the lowest income bracket.

\section{Incidence of Indirect education costs}

From the information in Table $m$, we are able to estimate the incidence of the indirect costs of each type of higher education by making two simplifying assumptions: (1) Each person's contribution to the financing of the educational system is equal to his total tax bill multiplied by the fraction of the government budget which is spent on education. (2) His contribution to each type of higher education is proportional to the importance of that type of education in the over-all educational budget. The percentage of taxes paid to finance a particular type of higher education is then multiplied by the average tax bill within an income bracket to give an estimate of the tax contribution for each type of higher education by income bracket. ${ }^{17}$ These are found to range from a high of shs. 63 for the highest

\section{See [1]}

16 'African' is a racial term denoting blacks, as opposed to African (browns) and Europeans (whites)

17 To give an example of how these figures were constructed consider the contribution of a person in the highest income bracket to the financing of the University of Nairobi In 1969/70 the Kenya government spent 14 percent of its budget on education. 15 percent of the educational budget was spent on university education (6 per cent was spent on primary teacher training colleges and 3 percent on secondary teacher training colleges). Thus, an estimated 2-1 percent of a person's tax contribution went to financing the University. Persons in the highest income bracket paid an average of 12-5 percent of their incomes in taxes (see column 3 of Table III). Evaluated at the midpoint of the income bracket, we estimate this person to have paid shs. 2,970 in taxes. $2-1$ percent of shs. 2,970 is shs. 63 . The remaining figures were constructed 
income bracket for the most costly (university) down to shs. 0 for a lowest income bracket individual's contribution to the primary TTCs.

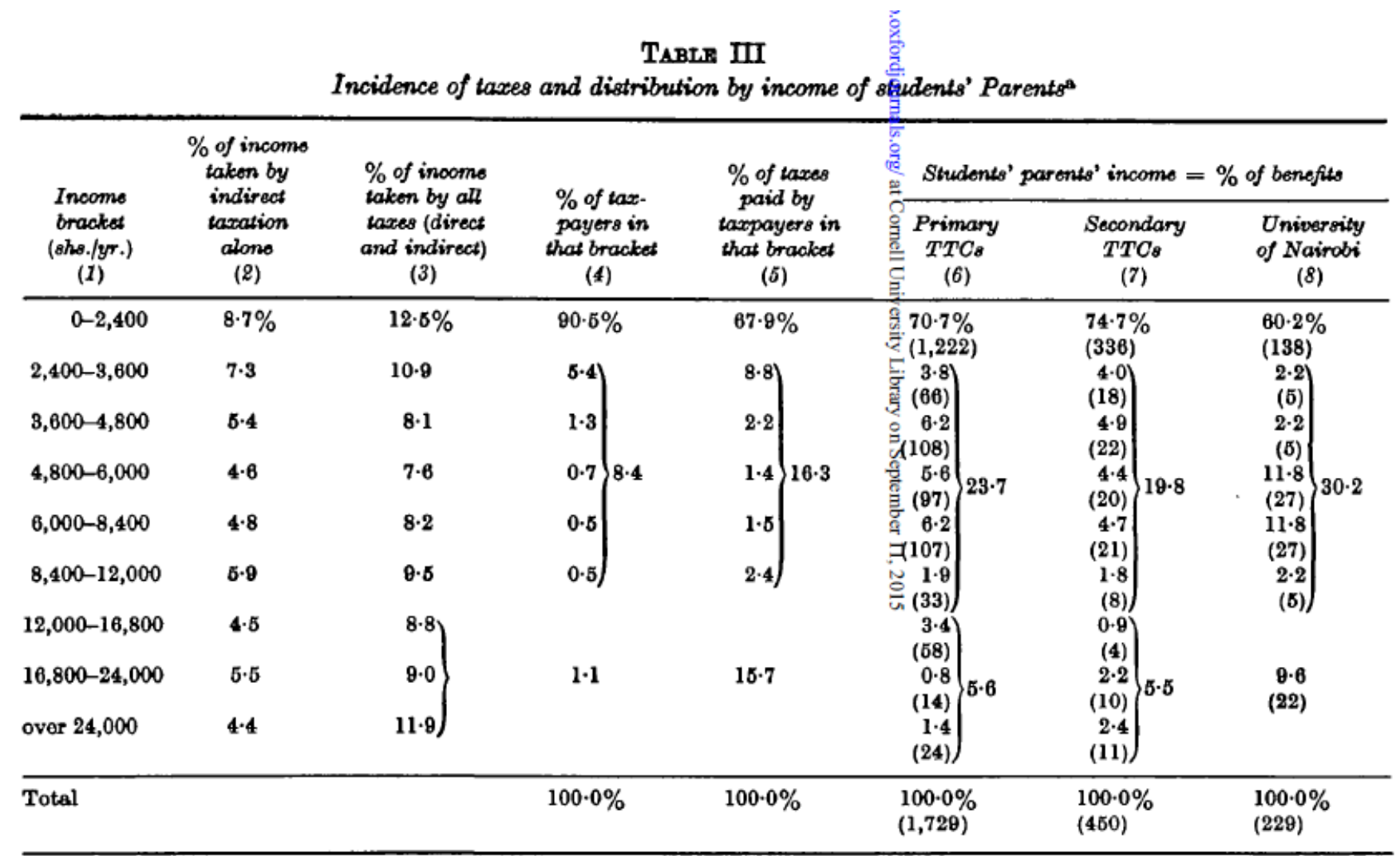

Sources of columns 2 and $3[11$, p. 10].

Columns (4) and (5) were caloulated by the author. Details of the calculations of columns (4) and (5) have been omitted due to spece limitations but are available from the suthor upon request.

- Number of students given in parentheses.

Compared with the private benefits from higher education and the earnings forgone while in school (cf. Table II), these tax costs are trivial. Clearly, the families whose children receive higher education are subsidized by the other families whose children are not educated at this level. Thus, there is substantial horizontal inequity in the existing system of financing of higher education in Kenya.

\section{Approximation of students' families' incomes}

Having estimated the tax costs of Kenya's higher education system, we now seek to determine the number of students in each income category receiving each type of education, then calculate the costs of each type of higher education to families in each income bracket, and finally compare these with the present value of the benefits accruing to the educated individuals over their working lives. We will do this in Section 5, but first it is necessary to approximate the incomes of students' families based on the available socio-economic data. $^{18}$

It should be noted at the outset that Kenya is mainly an agricultural country. Only 627,000 of its more than ten million people are employed in the 'modem sector'. Furthermore, few persons sever their ties with agriculture, and there is a constant flow of workers

in a similar manner.

${ }^{18}$ Additional details regarding the procedures by which these approximations were made are available from the author upon request. 
back and forth from the cities and towns to the farms. For this reason, we must approximate both farm and non-farm income in determining a student's family's total income.

\section{A. Farm income}

Farm income has two components: land income and cattle income. The land income of $i^{\text {th }}$ farm $\left(L_{l}\right)$ is defined as:

$$
L_{i}=\sum_{j} A_{i} f_{i j} V_{i j}
$$

\section{where $A_{i}=$ acreage of farm $i, f_{i j}=$ fraction of $i$ 's acreage devoted to production of crop $j$, and $V_{i j}=$ value added per acre of crop $j$ on farm $i$.}

For empirical implementation, this definition of land income is modified by assuming (a) that the average fraction of land under cultivation on all Kenyan farms applied to each individual farm, and (b) that the land under cultivation was divided equally among the crops grown. ${ }^{19}$ In addition, it was not possible to estimate farm-specific or region-specific value added per acre of crop. Rather, the value added per acre of crop $j$ was the average figure for all farms in the country growing that crop. Thus, for empirical estimation, the land income of the $i^{\text {th }}$ farm is taken to be

$$
L_{i}=c \sum_{j}\left(\frac{A_{i}}{J_{i}} V_{j}\right)
$$

\section{where $c=$ average fraction of land under cultivation on all Kenyan farms, $A_{i}=$ acreage of farm $i, J_{i}=$ number of crops grown on the $i$ th farm, and $V_{j}=$ value added per acre of $j$ for all Kenyan farms.}

Farm-specific figures in (2) are derived from students' answers to the following survey questions: 'Does your father own any land? If "yes" how many acres does he own? Does your father (or your mother) grow any crops to sell for money? If "yes" which crops?' The crops listed as alternatives were coffee, tea, pyrethrum, cotton, and other. Figures for all Kenyan farms were derived from a small farm survey conducted by the Ministry of Agriculture covering 1,154 farms. ${ }^{20}$

The other component of farm income is the income attributable to cattle ownership. The cattle income of the ith farm is the

\footnotetext{
19 The rationale for these assumptions is that it became apparent in a pretest of the survey questions that students did not know what fraction of their father's land was under cultivation or how many acres were allocated to each crop.
}

20 Jerome Wolgin used these data for a doctoral dissertation at Vale; I am grateful to him for making the value added figures available to me. The average fraction of land under cultivation for crops to be sold for cash was 47 per cent. The average value added per acre planted was shs. 185 per year for both coffee and tea, 130 for pyrethrum, 162 for cotton, and 146 for other.

In addition, I used the data from the individual farms to test whether there were significant scale effects. Regressing value added per acre of crop $j$ on the number of acres of that crop in both the linear and double-logarithmic form, I found that the regression coefficients and coefficient of determination were in all cases insignificantly different from zero. In light of this, the use of a single value added per acre figure regardless of farm size would appear justified. 
number of grade cows multiplied by the value added per grade cow in the country as a whole plus the number of non-grade cows multiplied by the value added per non-grade cow. The annual value added per grade and non-grade cow were calculated from the Ministry of Agriculture's small farm survey and were found to be shs. 239 per year and shs. 34 per year respectively. Data on the tth farm's cattle ownership were taken from the student's response on the Parents' Occupation Questionnaire to the question: 'Does your father own any cattle? If "yes": how many non-grade (local) cattle does he own? If "yes": how many grade (exotic) cattle does he own?"

\section{B. Non-farm Income}

To determine the non-farm income of parents, students were asked: 'What kinds of work does your father (or guardian) do and who does he work for? Write down all the kinds of work he does and describe them as clearly as you can.' If more than one kind of work was reported, it was assumed that the father's time was divided equally among the different kinds. The responses were coded to conform with official government job categories.

Data on monthly cash remuneration for each job category are collected on a firm-by-firm basis by the Ministry of Finance and Economic Planning. ${ }^{21}$ Unpublished summary tabulations by one-digit industrial classification were made available to me by the Ministry for purposes of this study. For each job category, I took the average monthly cash remuneration in each industry, weighted each by the number of employees in that job category in that industry, and thereby constructed a weighted average of monthly cash remuneration in each job category for the country as a whole. The student's description of his parent's work was then matched with the average earnings in the occupational category to determine a proxy nonfarm income. ${ }^{22}$

\section{Total income}

The total income of an individual student's family was estimated as the sum of the farm and non-farm income derived in the manner described above, and frequency distributions are presented in columns 6-8 of Table UL These data reveal three outstanding features:

1. The students in Kenya's higher education system come from families with clearly higher incomes on average than Kenya's population as a whole.

2. University students come from higher income families than students in the teacher training colleges.

3. However, the majority of the students come from families which could not by any standard be considered 'the elite' (cf. Table I).

\section{Incidence of total costs paid and benefits received by income class}

As noted earlier, the vast majority of students in higher education work for government upon completion of their studies and are paid according to a fixed government salary scale. It seems reasonable therefore to assume that each recipient of higher education receives the same monetary benefit as any other. Thus, the distribution of students by income class also is the distribution of the benefits

${ }^{21}$ For a description of the survey and some of the findings, see [13].

22 This procedure, although the beet possible, is far from ideal. Many things other than occupation determine earnings (see [6]). However, national data on the correlates of earnings are not available, so it was impossible to make any further refinements. 
of higher education.

We have also seen that Kenya's higher education system is funded almost entirely by government. On the assumption that a person's contribution to a given fiscal programme is equal to his total tax contribution multiplied by the ratio of spending on the fiscal programme in question to total government spending, the percentage of all taxes paid by persons in each income bracket also is the distribution of direct costs of higher education.

From the distributions of benefits, tax costs, and taxpayers by income class as shown in Table EH, we find:

1. Low and higb income families each pay a larger share of the direct costs of the University of Nairobi than their respective fractions of the benefits; the reverse holds for middle income people.

2. For the teacher training colleges, the lower and middle income people each receive a larger fraction of the benefits than their respective shares of the costs; as with the University, high income people receive a smaller fraction of the benefits than their share of the costs.

3. Low income people pay a smaller percentage of the costs relative to their numbers in the population; middle and upper income people pay more.

4. Relative to their numbers in the population, children of low income families are underrepresented in the higher education system, middle and high income children overrepresented.

Qualitatively, these results are not very different from studies of the higher education systems of California [4] [5] and Canada [7].

\section{Conclusion}

In this paper, we have examined Kenya's higher education system with the goal of testing among three alternative hypotheses: that the higher education system redistributes income from rich to poor, that it redistributes income from poor to rich, or that it has no important effect on the distribution of income.

In testing the inter-generational version of these hypotheses, we have adopted a so-called 'Equal Opportunity Criterion', whereby the educational system is equitable if different income groups have access to opportunities for higher education in proportion to their numbers in this population. By this criterion, Kenya's higher education system is found to be inequitable inter-generationally, since the few who are favoured are disproportionately the children of the well-to-do, whether measured by income class or various indices of socio-economic status. ${ }^{23}$ For instance, 00 per cent of the students at the University of Nairobi are found to come from families in the lowest income brackets, but this bracket includes 90 per cent of the taxpayers.

The intra-generational version of these hypotheses may be tested by either of two criteria. According to the 'Cost-Benefit Criterion', by which a programme is held to be equitable if each group in the population pays a fraction of the costs equal to the fraction

23 The fact that the educational system is inequitable in this sense does not necessarily imply that the gap in opportunities could be lessened within the educational system. For in the absence of an educational system, the children of the well-todo might have an even more exclusive hold on certain types of jobs. I thank the Editor for making this point to me. 
of the benefits they receive, we have found that there is something akin to vertical equity in the financing of Kenya's higher education system. The lowest income group pays a somewhat larger percentage of the direct costs of the University of Nairobi than it receives in benefits, but the reverse is true for the teacher training colleges. However, if alternatively we adopt the 'Ability to Pay Criterion', according to which a programme is equitable if the cost-benefit ratio rises as a function of income, the approximate vertical proportionality is inequitable and favours the well-off.

We should observe, though, that the main inequity in Kenya's higher education system, though this is by no means unique to that particular country, is horizontal. A select few receive a very large payoff and if they were not relatively rich when they started their higher education, they will be relatively rich when they complete it. In other words, the system is horizontally inequitable ex poet though less so ex ante. While the amounts involved on a person-by-person basis are very small on the tax side, they are very substantial per person on the benefit side.

At first glance, it might appear that it is the higher education system which is responsible, but this does not seem to be the case. Rather, the cause seems to be adverse selection at the primary and secondary levels. Although the costs of schooling at these levels are heavily subsidized (about 80 per cent), pupils themselves must pay the remaining 20 per cent. This is a large and often overwhelming burden for many families, and as a result, many children are simply unable to attend. Even if they are able to get together the fees, poor families frequently find that they cannot forgo their children's labour during planting and harvest seasons. For such families, the quality of the education received undoubtedly suffers. And since admission to the higher education system is conditional on succeeding on examinations at earlier levels, there is a systematic process operating against the poor.

The policy conclusion which follows from these findings is straightforward. In the absence of fundamental changes in the tax structure and/or wage structure, both the horizontal inequity at the higher education levels and the adverse selection at the lower levels could nevertheless be lessened by charging students the full costs of their education to be repaid over their working lives ${ }^{1}$ and using the proceeds to provide selective subsidies for the primary and secondary education of the children of the poor. In [2], I have estimated that this would permit virtually universal primary education under present financial arrangements or permit the abolition of fees of all those now attending, while at the same time having little discouraging effect on the private attractiveness of investment in higher education, since private rates of return would remain very high (19 per cent for university, 23 per cent for secondary teacher training, and 21 per cent for primary teacher training). In this way, Kenya's higher educational system could contribute more to achieving 'a fundamental objective of the Government... a just distribution of the national income'.

\section{REFERENCES}

1. DiejomaOH, V. P., 'Tax mobilisation and government development financing in Kenya', Institute for Development Studies, University of Nairobi, Discussion Paper No. 80, Nov. 1909.

2. FieLDS, G. S., 'Private returns to investment in higher levels of education in Kenya', in Court, David, and Ghai, Dharam, ed., Society, Education, and Development: Some Perspectives from Kenya, Oxford University Press, forthcoming.

3. GHAl, D. P., 'Employment performance, prospects and policies in Kenya', to be published in proceedings of the 1970 Cambridge Conference on 'Employment Opportunities in the Seventies'. 
4. Hansen, W. L., and WeISBBod, B., Benefits, Costs, and Finance of Public Higher Education, Chicago, Markham Publishing Company, 1970.

5. HabtMan, R., 'A comment on the Pechman-Hansen-Weisbrod controversy', Journal of Human Resources, Fall, 1970.

6. JohnsON, G. E., 'An empirical model of the structure of wages in urban Kenya', Department of Economic», University of Michigan, June, 1972, mimeo.

7. JUDY, R. W., 'On the income redistributive effects of public aid to higher education in Canada', Institute for Policy Analysis, University of Toronto, Sept. 1969.

8. PeChMAn, J., 'The distribution effects of public higher education in California', Journal of Human Resources, Summer, 1970.

9. RAST AD, S. E., 'University students and the employment market-a profile of present graduates of University College, Nairobi', Institute for Development Studies, University of Nairobi, Staff Paper No. 74, June 1970.

10. Westlake, M. J., 'Kenya's extraneous and irrational system of personal income taxation', Institute for Development Studies, University of Nairobi, Staff Paper No. 101, June 1971.

11. ----'Kenya's indirect tax structure and the distribution of income', Institute

for Development Studies, University of Nairobi, Staff Paper No. 102, June 1971.

${ }^{1}$ Details of such a scheme may be found in [2J.

12. Republic of Kenya, Development Plan: 1970-1974, Nairobi, Government Printer.

13. Republic of Kenya, Ministry of Finance and Planning, Employment and Earnings in the Modem Sector, 1968-1970, Nairobi, Government Printer.

14. Republic of Kenya, 1970 Statistical Abstract, Nairobi, Government Printer.

Sources of columns 2 and $3[11$, p. 10].

Columns (4) and (5) were calculated by the author. Details of the calculations of columns (4) and (6) have been omitted due to space limitations but are available from the author upon request. 